\title{
An Active Site Arginine Residue in Tobacco Acetolactate Synthase
}

\author{
Sung-Ho Kim, En-Joung Park, Sung-Sook Yoon, and Jung-Do Choi \\ School of Life Sciences and Biotechnologv Research Institute, Chungbuk Kational Chiversity, Cheongin 361-763, Korea \\ Received September 8, 2003
}

\begin{abstract}
Acetolatate synthase(ALS) catalyzes the first common step in the biosynthesis of valine. leucine, isoleucine in plants and microorganisms. ALS is the target of several classes of herbicides. including the sulfonylureas, the imidazolinones. and the triazolopy rimidines. To elucidate the roles of arginine residues in tobacco ALS, chemical modification and site-directed mutagenesis were performed. Recombinant tobacco ALS was expressed in $E$. coli and purified to homogeneity. The ALS was inactivated by arginine specific reagents, phenylglyoxal and 2,3-butanedione. The rate of inactivation was a function of the concentration of modifier. The inactivation by butanedione was enhanced by borate. and the inactivation was reversible on removal of excess butanedione and borate. The substrate pyruvate and competitive inhibitors fluoropyruvate and phenylpyruvate protected the enzyme against inactivation by both modifiers. The mutation of well-conserved Arg198 of the ALS by Gln abolished the enzymatic activity as well as the binding affinity for cofactor FAD. However, the mutation of R198K did not affect significantly the binding of FAD to the enzyme. Taken together, the results imply that Arg 198 is essential for the catalytic activity of the ALS and involved in the binding of FAD. and that the positive charge of the Arg is crucial for the interaction with negatively charged FAD
\end{abstract}

Key Words : Acetolatate synthase. Herbicide. Arginine. Chemical modification. Site-directed mutagenesis

\section{Introduction}

Acetolactate synthase (ALS, EC 4, 1.3.18: also referred to as acetohydroxy acid synthase) is an enzyme catalyzing the conmon step in the biosynthetic pathways of valine, leucine. and isoleucine in plants and microorganisms. The enzyme catalyzes two parallel reactions, the condensation of two molecules of pyruvate to 2 -acetolactate in the first step of biosynthesis of valine and leucine. and the condensation of pyruvate and 2-ketobutyrate to 2-aceto-2-hydroxybutyrate in the second step of isolencine biosynthesis. ${ }^{1}$ ALS requires three cofactors for its catalytic activity. thiamine pyrophosphate (TPP), flavin adenine dinucleotide (FAD). and a divalent metal ion. $\mathrm{Mg}^{2+}$ or $\mathrm{Mn}^{2+}$. ALS has attracted a great deal of interest because it had been known the target of several classes of structurally diverse herbicides. including the sulfonylureas..$^{2.3}$ the imidazolinones, ${ }^{+}$the triazolopyrimidines. ${ }^{5.6}$ and the pyrimidylbenzoates. ${ }^{7.8}$ Due to the structural diversity of the ALS-inhibiting herbicides it is believed that other classes of ALS inhibitors can be potentially utilized as herbicides or fungicides.

In bacteria. three ALS isozymes have been studied extensively in terms of their genetic regulation. structure. kinetic properties. feedback regulation and sensitivity to herbicidal inhibitors. ${ }^{9-12}$ However. the low abundance and labile nature of plant ALS have severely hampered the purification and biochemical studies of the enzrme. A number of ALS genes from Arabidopsis thaliona. ${ }^{13}$ Brassica napus. ${ }^{1+}$ Gossypium hirsutum. ${ }^{15}$ Nicotina tabactum. ${ }^{13}$ Zea mons. ${ }^{16}$ and Xonthirm sp. ${ }^{17}$ have been cloned and characterized.

To whom conespondence should be addressed. Tel: $+82-43-261$ 2308, Fax: +82-43-267-2306, e-mail: jdchoiacbucc.chungbuk ac.kr
ALS genes from $A$. thaliana $a^{18}$ and tobacco ${ }^{19}$ have been functionally expressed in $E$. coli. and each of the enzymes has been purified. Various herbicide-resistant ALS mutants from plants and bacteria have been obtained by spontaneous or induced mutation under the field or laboratory conditions and by site-directed mutagenesis ${ }^{l}$ (summarized in ref. (1)). Recently, site-directed mutagenesis studies of tobacco ALS in our laboratory have revealed that $\operatorname{Trp} 490,{ }^{20}$ Cys $411 .^{21}$ His 487,22 and Lys $219^{23}$ residues are essential for catalytic activity and that $\operatorname{Tr} 5573.2^{2}$ Alal21 and Ser652." and Lys $255^{23}$ are involved in the binding to herbicides. More recently, X-ray diffraction analysis of the crystal structure of the catalytic subunit of yeast ALS ${ }^{25}$ and kinetic analysis of the reaction of tobacco $\mathrm{ALS}^{26.27}$ were reported. Since the substrate pynuvate and cofactors FAD and TPP of ALS have negative charges. arginine residues charged positively are expected to be involved in the binding of the substrate and/or the cofactors.

In this study we carried out chemical modification and site-directed mutagenesis of arginine residues in tobacco ALS. and analyzed the effects of the modification and mutations on the enzymatic properties and the structure of the enzyme

\section{Experimental Section}

Materials. Bacto-try ptone. yeast extract. and Bacto-agar were purchased from Difco Laboratories (Detroit. USA). Restriction and modify ing enzymes were from Takara Shuzo Co. (Shiga. Japan) and Boehringer Manuheim (Mannheim. Germany). Thrombin protease and epoxy-activated Sepharose 6B were obtained from Pharmacia Biotech (Uppsala. Sweden). GSH. Sephadex G-25, TPP. FAD. $\alpha$-naphthol, creatine. 
phenylglyoxal, 2.3-butanedione. $\beta$-phenylpyruvate, $\beta$-fluoropyruvate were purchased from Sigma Chemical Co. (St. Louis, USA). Oligonucleotides were obtained from Jenotech (Taejeon. Korea). E. coll XLl-blue cells containing expression vector pGEX-ALS were provided by Dr. Soo-Ik Chang (Chungbuk National University. Cheongju. Korea). Londax (a sulfonylurea herbicide). and Cadre (an imidazolinone herbicide) were provided by Dr. Dae-Whang Kim (Korea Research Institute of Chemical Technology, Daejeon. Korea). TP. a triazolopyrinidine derivative. was obtained from Dr. Sung-Keon Namgoong (Seoul Women's University. Seoul, Korea).

Expression and purification of tobacco ALS. Bacterial strains of $E$. coll XLl-Blue cells containing the expression vector pGEX-ALS were grown at $37^{\circ} \mathrm{C}$ in Luria-Bertani (LB) medium containing $50 \mu \mathrm{g} / \mathrm{mL}$ anipicillin to an $O D_{\text {sici }}$ of 0.7-0.8. Expression of the pGEX-ALS gene was induced by adding $0.3 \mathrm{mM}$ isopropyl-D-thiogalactoside (IPTG). Cells were grown for an additional $4 \mathrm{~h}$ at $30^{\circ} \mathrm{C}$ and harvested by centrifugation at $5000 \mathrm{~g}$ for $30 \mathrm{~min}$. Purification of recombinant ALS was performed as described by Chang et $a{ }^{19}$ The cell pellets were resuspended with the standard buffer $(50 \mathrm{mM}$ Tris- $\mathrm{HCl}, \mathrm{pH} 7.5,1 \mathrm{mM}$ pyruvate, $10 \%(\mathrm{v} / \mathrm{v})$ ethylene glycol, $10 \mathrm{mM} \mathrm{MgCl}$ ) containing $2 \mu \mathrm{g} / \mathrm{mL}$ Leupeptin. $+\mu \mathrm{g} / \mathrm{mLL}$ Aprotinin, and $2 \mu \mathrm{g} / \mathrm{mL}$ Pepstatin A. The cell suspension was then lysed by sonication at $4^{\circ} \mathrm{C}$. The homogenate was centrifuged at $20,000 \mathrm{~g}$ for $20 \mathrm{~min}$ and the supernatant was re-centrifuged. The supernatant was applied on a GSH-coupled Sepharose 6B column preequilibrated with the standard buffer. After removing unbound proteins by washing with sufficient volume of standard buffer, the GST-ALS fusion protein was recovered from the colunu with the elution buffer ( $50 \mathrm{mM}$ Tris- $\mathrm{HCl}, \mathrm{pH} 7.5 .15$ mM GSH. $10 \mathrm{mM}$ ethy lene glycol). To obtain pure ALS. the fusion protein was digested by thrombin protease $(10 \mathrm{U} / \mathrm{mg}$ protein) overnight at $4{ }^{\circ} \mathrm{C}$. The ALS was purified by an additional step of GSH-affinity chrontatography. The isolated protein was identified by SDS-PAGE analysis ${ }^{\text {?ैy }}$ and the protein concentration was determined by the method of Bradford. ${ }^{29}$

Modification of ALS with phenylglyoxal and 2,3butanedione. Modification reactions with phenylglyoxal were carried out at $25^{\circ} \mathrm{C}$ in $50 \mathrm{mM}$ phosphate buffer $(\mathrm{pH}$ 8.0) according to the method of Choi et al. ${ }^{31}$ All other conditions were indicated in the figure legends. Aliquots of reaction mixture were removed at time interval and the enzyme was separated using Micro Bio-Spin 6 column. And then the enzyme activity was assayed. Activity is expressed as the ratio of the activity of the modified enzyme. $V$, to that of the control. $V_{c}$, multiplied by 100 . Modifications with butanedione were carried out as described in the procedure for modification with phenylglyoxal. To determine the reversibility of butanedione inactivation upon removal of excess butanedione and borate, the enzyme was first inactivated to $15 \%$ of a control in $50 \mathrm{mM}$ borate $(\mathrm{pH} 8.0)$. The inactivated enzyme was then freed from butanedione and borate using Micro Bio-Spin 6 column equilibrated with $50 \mathrm{mM}$ potassium phosphate buffer $(\mathrm{pH} 8.0)$. The modified enzyme solution was periodically assayed for activity over a period of incubation at $25^{\circ} \mathrm{C}$ and compared with that of a control.

Site-directed mutagenesis. Site-directed mutagenesis of tobacco ALS was performed directly on the plasmid derived from pGEX-2T containing tobacco ALS CDNA using the PCR megaprimer method. ${ }^{31}$ All manipulations of the DNA were carried out using the technique reported previously. The PCR was also performed as described previously. ${ }^{33}$ The first PCR was carried out with oligonucleotide primer NKB2 and each mutagenic fragment as internal primers. with the underlined bases changed

\section{NKB2, 5'-CCCGGGGATCCTCAAAGTCAATA-3' R198Q. 5'-GTGCCACGTCAGATGATGATCGG-3' R198K. 5'-GTGCCACGTAAAATGATGATCGG-3' R198A. 5'-GTGCCACGTGCTATGATGATCGG-3' NKB1. 5'-CATCTCCGGATCCATGTCCACTACCCAA-3'}

The bold bases are BamHI restriction site. Each reaction mixture contained $50 \mathrm{ng}$ of template DNA, $25 \mathrm{pmol}$ of mutagenic primer and universal primer NKB2, $200 \mathrm{uM}$ dNTPs in $50 \mathrm{mM} \mathrm{KCl} .10 \mathrm{mM}$ Tris $(\mathrm{pH} 7.5$ ). and $1.5 \mathrm{mM}$ $\mathrm{MgCl}_{2}$ in $100 \mathrm{uL}$. Each reaction was performed for 30 cycles of the following programs; $94{ }^{\circ} \mathrm{C} .1 \mathrm{~min} ; 60{ }^{\circ} \mathrm{C} .1 \mathrm{~min} ; 72$ ${ }^{\circ} \mathrm{C}, 2 \mathrm{~min}$. The resulting DNA was subjected to a second PCR with the universal primer NKBI. The PCR products were double digested with $N c o I$ and $B g / I \mathrm{I}$ and cloned into the expression vector. which was prepared from the $\mathrm{Ncol} /$ $B g / I I-e x c i s e d$ pGEX-wALS. The resulting pGEX-mALS was used to transform the $E$. coli XLI-Blue cells using standard $\mathrm{CaCl}_{2}$ transfonmation instruction. ${ }^{32}$ Each mutant ALS gene was sequenced by the dideosy chain termination procedure. ${ }^{3-4}$

Enzyme assay. Enzyme activity was measured according to the method of Westerfeld ${ }^{25}$ with a modification as reported previously. ${ }^{20}$ The reaction mixture contained 50 $\mathrm{mM}$ potassium phosphate buffer (pH 7.5). $1 \mathrm{mM}$ TPP, 10 $\mathrm{mM} \mathrm{MgCl}$. 20 uM FAD, $100 \mathrm{mM}$ pyruvate. and the enzyme in the absence or presence of various concentrations of inhibitors. The enzyme reaction was terminated by adding 6 $\mathrm{N} \mathrm{H}_{2} \mathrm{SO}_{4}$ solution, then the reaction product acetolactate was allowed to decarboxylate at $60^{\circ} \mathrm{C}$ for $15 \mathrm{~min}$. The acetoin formed by acidification was colorized with $0.5 \%$ creatine and $5 \%$ naphthol. The absorbance of the reaction mixture was measured at $525 \mathrm{~mm}$.

Spectroscopic measurements. Absorption spectra were recorded on a Bechman DU-600 UV/VIS spectrophotometer. The enzyme solution was dispended in $1 \mathrm{~mL}$ black-walled quartz cuvette, and each sample was scanned in the range of 250 to $550 \mathrm{~lm}$. Fluorescence emission spectra were recorded with a Perkin-Elmer Luminescence Spectrophotometer LS50B. The fluorescence spectra of FAD bound to wALS and mALS were obtained in the range of 450 to $650 \mathrm{~nm}$ by exciting at $450 \mathrm{~nm}$. 


\section{Results and Discussion}

Expression and Purification of Tobacco ALS. Wild-type tobacco ALS and the mutant ALSs (R198Q. R198K, and R198A) were expressed in $E$. coll as the GST-ALS fusion proteins. The wALS and two mutants, RI98Q and RI98K. were successfully expressed as a soluble form. as judged by SDS-PAGE. However. the mutant RI98A was expressed as only inclusion body under various conditions (data not shown). The resulting GST-ALS in a soluble form was purified to homogeneity in a single step by GSH-Sepharose $6 \mathrm{~B}$ affinity chromatography. Lane 2 in Figure $\mathrm{I}$ is a sample of purified GST-wALS. The purified GST-ALS protein was subjected to digestion with thrombin protease. The cleaved ALS enzyme was purified to homogeneity by an additional GSH-Sepharose chromatographic step. A single band of wALS, R198Q. and R198K at $66 \mathrm{kDa}$ appeared on the SDSPAGE (Fig. 1). The molecular mass of $66 \mathrm{kDa}$ for the subunit of recombinant tobacco ALS is in good agreement

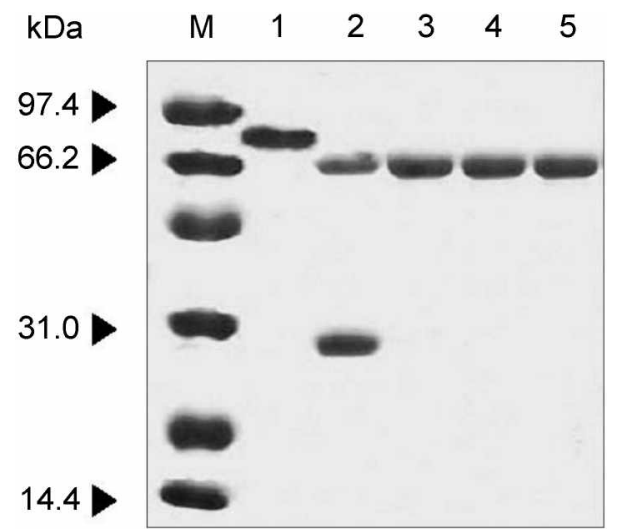

Figure 1. SDS-PAGE of wild-type ALS and mutant ALSs. Each sample was electrophoresed on $11 \%$ polyacrylanide gel containing SDS, then the gel was stained with Coomassie Blue. M, molecular marker, 97.4, 66.2, 45.0,31.0,21.5, 14.4 kDa; lane 1, GST-wALS fusion proteni; lane 2, wALS and GST from thrombin digestion of GST-wALS: lane 3, wALS: lane 4, R197Q; lane 5, R198K

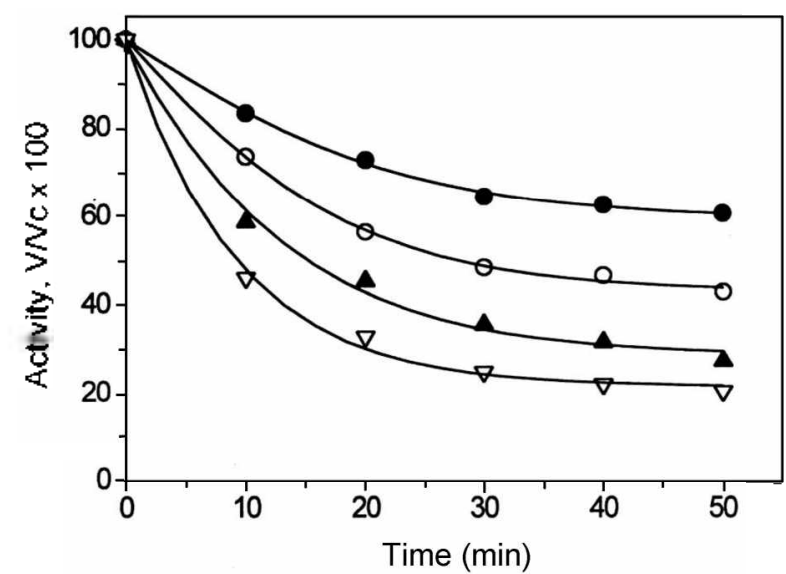

Figure 2. Inactivation of tobacco ALS by phenylglyoxal. The enzyme $(1.5 \mu \mathrm{M})$ was incubated with $2(\bullet), 4(\%), 8(\Delta)$, and 10 $(\because) \mathrm{mM}$ pheny lolyoxal in $50 \mathrm{mM}$ potassium phosphate buffer $(\mathrm{pH}$ $8.0)$ at $25^{\circ} \mathrm{C}$ with the value reported previously by Chang $e t a l^{19}$

Inactivation of Tobacco ALS by Phenylglyoxal and 2,3Butanedione. Recombinant tobacco ALS was inactivated with arginine specific reagent phenylglyoxal in potassium phosphate buffer, $\mathrm{pH} 8.0$. The rate of the ALS inactivation was a function of the reagent concentration (Fig. 2). The inactivation reaction followed roughly pseudo-first order kinetics during reaction period of fast phase. usually for 30 to $40 \mathrm{~mm}$. The second order rate constant for the inactivation during the period was approximately $4.6 \mathrm{M}^{-1} \mathrm{~min}^{-1}$ and that the constant was comparable with that of the inactivation of pyridoxamine 5 -phosphate oxidase with phenylglyoxal. ${ }^{3 i j}$ Another arginine reagent 2.3-butanedione also inactivated the ALS in borate buffer. and the inactivation was dependent on butanedione concentration (Fig. 3). The second order rate constant for the inactivation by butanedione in $50 \mathrm{mM}$ borate

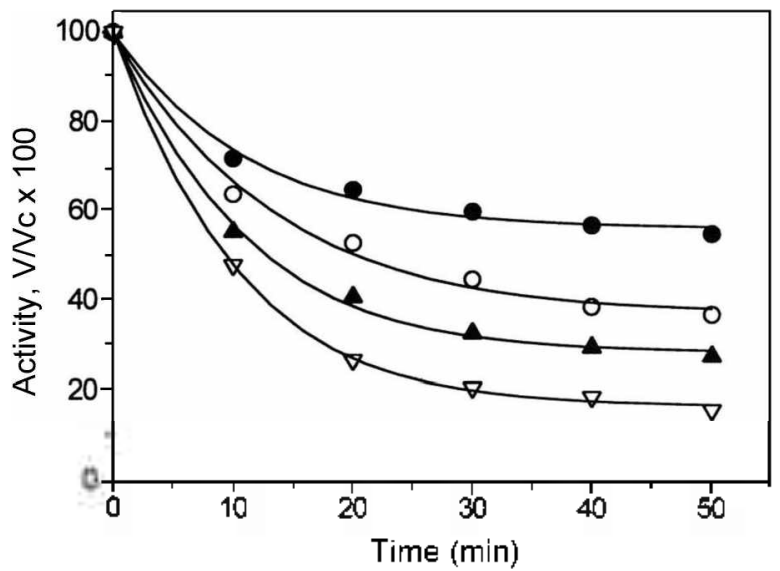

Figure 3. Inactivation of tobacco ALS by 2,3-butanedione. The enzyme $(1.5 \mu \mathrm{M})$ was incubatied with $5(\bullet), 10(\mathrm{a}), 15(\Delta)$, and $20(\because) \mathrm{mM} 2,3$-dutandione in $50 \mathrm{mM}$ borate buffer $(\mathrm{pH} 8.0)$ at $25^{\circ} \mathrm{C}$.

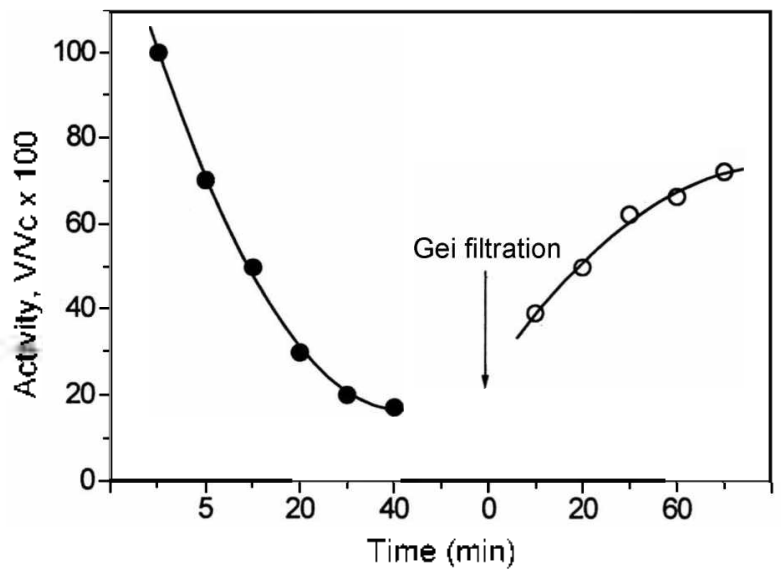

Figure 4. Reversibility of enzyme activity on the inactivation of tobacco ALS by 2,3-butanedione. The enzyme $(1.5 \mu \mathrm{M})$ was incubated with $20 \mathrm{mM} 2,3$-butanedione in the presence $50 \mathrm{mM}$ borate buffer, $\mathrm{pH} 8.0$ ( $\bullet$ ). The enzyme inactivated in borate bufter was separated from excess 2,3-butanedione and borate on a Micro Bio-Spin 6 column and periodically assayed for activity during incubation in $50 \mathrm{mM}$ potassium phosphate buffer $(\mathrm{pH} 8.0)$ at $25^{\circ} \mathrm{C}$ $(\because)$ 
buffer was about $2.9 \mathrm{M}^{-1} \mathrm{~min}^{-1}$ in fast phase. However. the inactivation by butanedione in phosphate buffer was much slower than that in borate buffer. After incubation of the ALS with $10 \mathrm{mM}$ butanedione for $50 \mathrm{~min}$ at $25^{\circ} \mathrm{C}$. the residual activity of the ALS was $62 \%$ and $38 \%$ of a control in $50 \mathrm{mM}$ phosphate and $50 \mathrm{mM}$ borate buffer, respectively. The inactivation by butanedione was reversible upon removal of excess butanedione and borate (Fig. 4). The ALS. which had lost about $85 \%$ of its original activity by incubation with butanedione-borate, was restored to about $70 \%$ of the control within $80 \mathrm{~min}$ of incubation at $25{ }^{\circ} \mathrm{C}$ following removal of excess butanedione and borate (Fig. 4). The characteristics of butanedione modification of this kind have been observed for many arginyl enzymes. ${ }^{30.36-38}$ The substrate pyruvate and competitive inhibitors fluoropyruvate and phenylpyruvate effectively protected the enzyme against the inactivation by phenylglyoxal and 2.3-butanedione (Fig. 5A and $B$ ). Phenylglyoxal has been shown to be highly selective for the modification of arginyl residues in proteins. ${ }^{3 i j .39 .+1 i}$
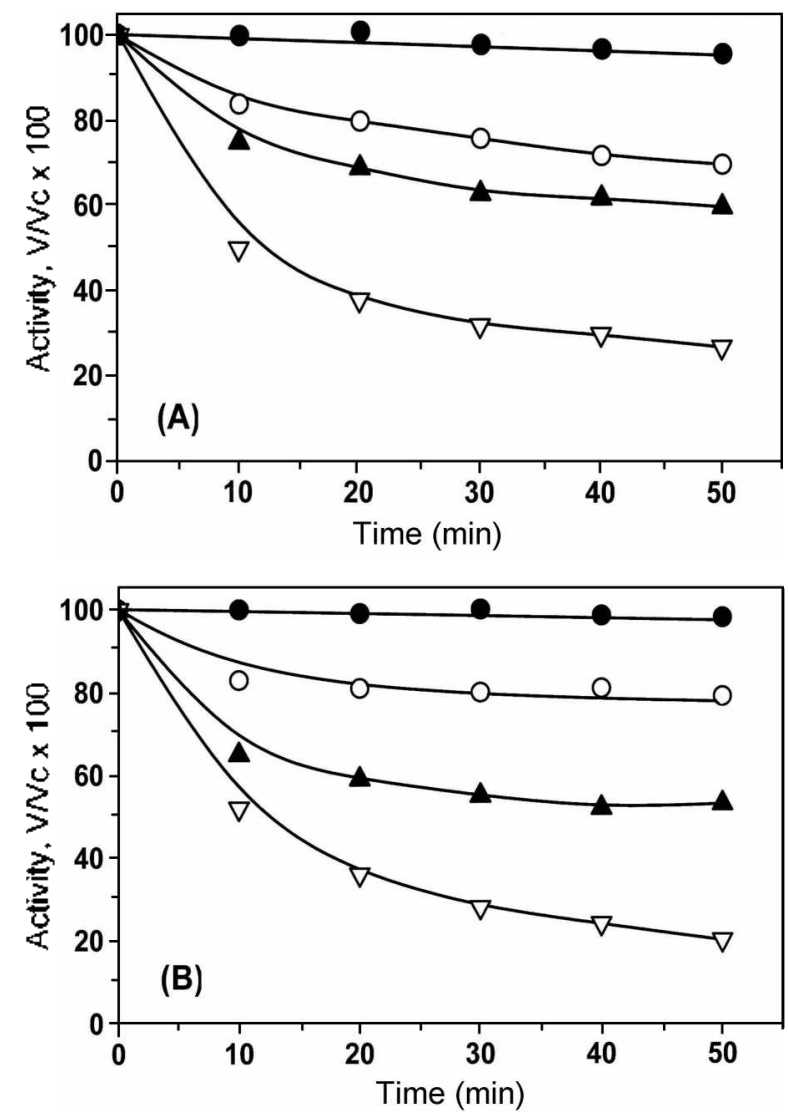

Figure 5. Protective effect of substrate pyruvate and competitive inhibitors fluoropynuvate and phenvlpynuvate on the inactivation of tobacco ALS by phenylglyoxal and 2,3-butanedione. Enzyme activity was assayed after removal of the reagent and substrate inhibitor using Micro Bio-Spin 6 column. A: The enzyme (1.5 $\mu \mathrm{M}$ ) was incubated with $10 \mathrm{mM}$ phenlglvoxal in the absence $(\because)$ and the presence of $40 \mathrm{mM}$ pynvate ( $), 0.1 \mathrm{mM}$ fluoropyruvate $(\bullet)$, and $0.5 \mathrm{mM}$ pheny lpyruvate $(-)$. B: The enzyme $(1.5 \mu \mathrm{M})$ was incubated with $20 \mathrm{mM}$ 2,3-butanedione in the absence $(\because)$ and the presence of $40 \mathrm{mM}$ pyruvate ( 4$), 0.1 \mathrm{mM}$ fluoropyruvate $(\bullet)$ and $0.5 \mathrm{~mm}$ phenylpyruvate (a).
2.3-Butanedione is even more selective for the modification of arginine residues in proteins..$^{3 i .36 .41}$ The butanedione modification has shown that the reaction is enhanced by borate buffer. which stabilizes the cis-amino-carbinol adduct formed between guanidine group and butanedione. and further reversible by removal of excess butanedione and borate. ${ }^{36,+1}$ In this study with tobacco ALS, the inactivation by butanedione is augmented by borate and reversible on removal of borate in consistent with the mechanism proposed by Riordan. ${ }^{36}$ Thus, the inactivation of the ALS by treatment with phenylglyoxal and butanedione is most likely due to modification of arginine residue(s) in the enzyme. When the loss of enzyme activity is observed on the modification of amino acid residues of the enzyme, there are several possibilities for the inactivation of the enzyme. The modification of essential amino acid residue(s) may be responsible for the inactivation of the enzyme. One could presume that the conformational change, aggregation, or dissociation to subunits induced by modification of amino acid residues may cause inactivation of the enzyme. However, in this case the modification of essential arginine residue(s) is most likely responsible for the inactivation of the ALS, since the substrate and competitive inhibitors effectively protected the enzyme against the inactivation. In a number of enzymes, arginine residues have been shown to be essential to serve as positively charged recognition site for negatively charged substrate and anionic cofactor, particularly phosphate and carboxylate group ${ }^{42}$ (references therein).

Site-directed Mutagenesis of an Arginine Residue of Tobacco ALS. Since the chemical modification studies suggested that arginine residues are important for catalytic activity of tobacco ALS, site-directed mutagenesis of wellconserved Arg198 was performed to identify the essential arginine residue. Three mutants (R198Q. R198K, and R198A) of tobacco ALS gene were cloned into the bacterial expression plasmid pGEX-2T. Each of the ALS mutants was expressed in $E$. coli as a GST-ALS fusion protein. Two mutants, R198Q and R198K. were successfully expressed as a soluble form. But the mutant R198A was expressed only as inclusion body under various conditions.

Although the R198Q mutant was expressed and purified normally like wild-type ALS (Fig. 1), it has not shown any detectable enzymatic activity under various assay conditions. To understand the inactivation mechanism, the spectroscopic properties of RI98Q mutant were compared with those of wALS. The absorption spectrum of the cofactor FAD bound to wALS showed peaks around 370 and $450 \mathrm{~nm}$ (Fig. 6). similar to that reported previously. ${ }^{20}$ In contrast, the spectrum of R198Q showed no comparable peaks in the region of 350 to $500 \mathrm{~nm}$. superimposed on the background that rises progressively to the lower wavelength region (Fig. 6). The fluorescence emission spectrum of R $198 \mathrm{Q}$ showed no peak around $530 \mathrm{~mm}$ by exciting at $450 \mathrm{~mm}$. which is the emission peak of FAD bound to wALS (Fig. 6. inset).$^{201}$ Both the absorption and fluorescence spectra of R198Q indicate that the mutant R198Q does not bind the cofactor FAD. Taken 


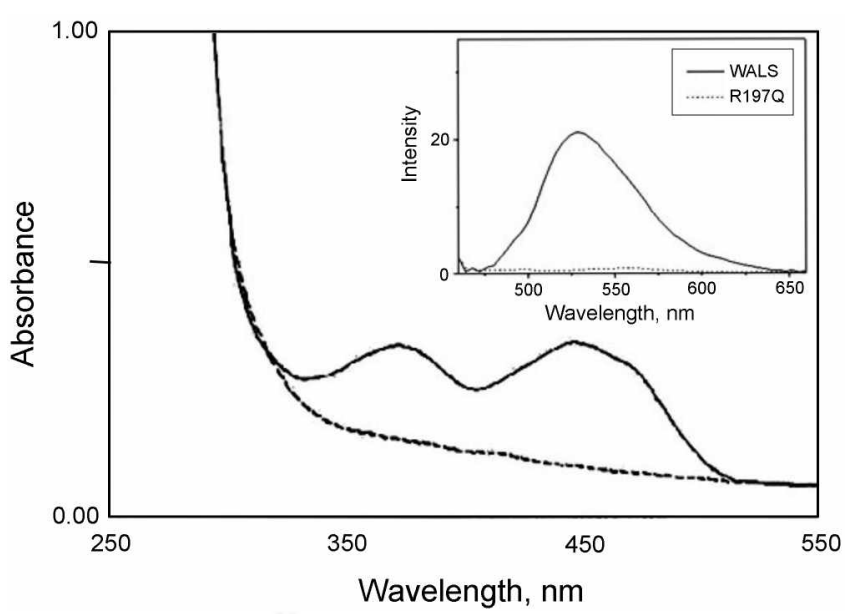

Figure 6. Absorption spectra of wALS and R197Q. The concentration of each enzrme was $16 \mu \mathrm{M}$ in $50 \mathrm{mM}$ Tis-HCl buffer $(\mathrm{pH} 7.5)$. wALS, solid line: RI98Q, dashed line. Insert is Fluorescence spectra of wALS and R197Q.

together. the results strongly suggest that Arg 198 is essential for the cataly tic activity and probably involved in the binding of FAD.

To understand the role of positive charge of arginine side chain. R198 was replaced by a lysine which has also positive charge at the side chain. The mutant R198K was active and showed a character similar to wALS with respect to the kinetic properties, including $\mathrm{K}_{\mathrm{m}} . \mathrm{K}_{c}$ for FAD and TPP, and $\mathrm{K}_{1}^{\mathrm{app}}$ of three herbicides, NC-31 1, Cadre. and TP (Table. 1). The values of $V_{\text {max. }} K_{m}$. and $K_{c}$ for each cofactor were deternined by fitting the data to $\mathrm{Eq}$. (1) by the non-linear least -square Sintplex method for error minimization. ${ }^{\text {th }}$

$$
\mathrm{v}=\mathrm{V}_{\text {max }} /(1+\mathrm{K} /[\mathrm{X}])
$$

In this equation, $v$ is the reaction velocity, $V_{\max }$ is maximun velocity. and $K$ is $K_{r}$ or $K_{4}$ depending on the varied component concentrations [X] of a substrate or cofactor. The $V_{\text {max }}$ of $\mathrm{R} 198 \mathrm{~K}$ was smaller more than 10 -fold than that of wALS. However, other parameters, $K_{m}$ and $K_{c}$ were not affected significantly by the mutation.

The sensitivity of RI98K to the inlibition by ALS-target herbicides. NC-311 (a sulfonylurea). Cadre (an imidazolinone), TP (a triazolopyrimidine) was determined. The $\mathrm{K}_{1}^{\text {app }}$ values were obtained by fitting the data to Equation (2).

$$
\mathrm{v}_{\mathrm{l}}=\mathrm{v}_{0} /\left(1+[\mathrm{I}] / \mathrm{K}_{1}^{\mathrm{app}}\right)
$$

In this equation. $v_{1}$ and $v_{0}$ represent the reaction rate in the presence and absence of the inhibitor. respectively. and [I] is the concentration of inhibitor. The $\mathrm{K}_{\mathrm{l}}^{\text {apf }}$ is the apparent $\mathrm{K}_{1}$, that is the concentration of the inlibitor giving $50 \%$ inhibition under a standard assay condition. and which is also known as $\mathrm{IC}_{5 i j}$. Three classes of herbicides, $\mathrm{NC}-31 \mathrm{l}$, Cadre. and TP are very potent inhibitors of wALS with $\mathrm{K}_{1}^{\mathrm{apF}}$ values of $61.5 \mathrm{nM}, 1.8 \mathrm{uM}$, and $16.0 \mathrm{uM}$. respectively (Table 1). The inhibition of RI98K by each of the herbicides is similar to that of wALS (Table 1). indicating that the mutation affects little the binding of the herbicides. Thus. it inplies that Arg198 is not directly involved in the binding of the herbicides.

It was noticed by a homology search for ALS genes of bacteria. yeast, and plants that Arg 198 of tobacco ALS is well conserved. 'A molecular model for the active site of Arabidopsis thaliana ALS was generated based on the X-ray structure of TPP-dependent pyruvate oxidase. sequence homology of the two proteins. and the results of mutation of the ALS. ${ }^{18}$ Biochemical. genetic, and structural similarity of ALS and pyruvate oxidase suggested a common ancestral origin for these enzymes. ${ }^{43}$ Moreover. a low level of ALS activity was demonstrated by pyruvate oxidase itself. and also by a chimeric protein consisting of the $\mathrm{N}$-terminal half of pyruvate oxidase and C-terminal half of ALS. ${ }^{43}$ According to the model, Arg 199 of Arabidopsis ALS (corresponding to Arg 198 of tobacco ALS) is located near the entrance of the active site pocket and in close proximity of the overlapping region for the binding of cofactor $\mathrm{FAD}$ and a herbicide imidazolinone. ${ }^{18}$ The result from the mutation of R198Q. which caused to lose both the enzymatic activity and binding affunity for FAD, suggests that Arg 198 is located at the active site of the ALS and possibly involved in the binding of FAD. And this result is in good agreement with the proposed model. ${ }^{18}$ In chemical modification study, the substrate and competitive inhibitors protected the enzyme against inactivation by the arginine reagents. It could be suggested that the binding of substrate or inhibitor prevents the access of the modifier to the essential Arg 198.

The replacement of Arg 198 by Lys containing positively charged side chain like Arg affected marginally the kinetic properties, the binding affinities for cofactors FAD and TPP, and the inhibition sensitivity by the herbicides $\mathrm{NC}-31 \mathrm{l}$, Cadre. and TP. Thus, it indicates that the positive charge of Arg 198 has an essential role in the interaction with negatively charged cofactor FAD.

\begin{tabular}{|c|c|c|c|c|c|c|c|}
\hline & \multirow{2}{*}{$\begin{array}{c}\mathrm{K}_{\mathrm{m}} \\
\text { Pyruvate, } \mathrm{mM}\end{array}$} & \multirow{2}{*}{$\frac{V_{\max }}{\text { U-mg }^{-1}}$} & \multicolumn{2}{|c|}{$\mathrm{K}_{\mathrm{i}}$} & \multicolumn{3}{|c|}{$\mathrm{K}_{1}^{\text {apP }}$ Value for inhibitors } \\
\hline & & & $\mathrm{FAD}, \mathrm{uM}$ & $\mathrm{TPP}, \mathrm{mM}$ & $\mathrm{NC}-3 \mathrm{II}, \mathrm{nM}$ & Cadre, uM & $\mathrm{TP}^{\mathrm{l}}, \mathrm{nM}$ \\
\hline WALS & 15.5 & 5.59 & 1.69 & 0.04 & 61.5 & 1.8 & 16.0 \\
\hline R198K & 4.68 & 0.36 & 1.89 & 0.2 & 28.4 & 1.3 & 8.1 \\
\hline R198Q & \multirow{2}{*}{\multicolumn{7}{|c|}{$\begin{array}{l}\text { No encymatic activity } \\
\text { Inclusion body }\end{array}$}} \\
\hline R198A & & & & & & & \\
\hline
\end{tabular}

Table 1. Kinetic parameters and Kiapp values of wALS and mALSs

For each enzyme. the values shown are the best fitting estimation of the parameter obtained from regression analysis. 'TP. a newly synthesized derivative of triazolopyrimidine sultonamide. 


\section{Conclusion}

Tobacco ALS was inactivated by arginine specific reagents phenylglyoxal and 2,3-butanedione. and the substrate and the competitive inhibitors protected the enzyme against the inactivation. This result suggests that the inactivation is likely due to the modification of an essential arginine residue at the active site of the enzyme. Site-directed mutation of well-conserved Arg198 by Gin resulted in losing the enzymatic activity as well as binding affinity for cofactor FAD. This indicates that Arg198 is essential for the catalytic activity and possibly involved in the binding of FAD. Since the replacement of Arg 198 by Lys affects little the enzymatic properties. the positive charge of the Arg seems to be crucial in the interaction with negatively charged FAD.

Acknowledgments. This work was supported by Korea Research Foundation Grant (KRF-2001-015-DP0348).

\section{References}

1. Duggleby R. G.: Pang. S. S. J. Biochem. Afol. Biol. 2000. 33. 1 .

2. LaRossa. R. A.: Schloss. J. V. J. Biol. Chem, 1984. 259.8753.

3. Ray T. B. Plam Phnsiol 1984. 75.827.

4. Shaner, D. L.: Anderson. P. C. Stidham. M. A. Plant Phnsiol. $1984,76,545$.

5. Gerwick, B. C.: Subramanian. M. V.: Loney-Gallant, V: Chander. D. P. Pest. Sci. 1990.29 .357$.

6. Namgoong. S. K.: Lee. H. J.: Kim. Y. S.: Shin. J.-H.: Che. J.-K.: Jang. D. Y.: Kim. G. S.: Yoo. J. W. Kang. M.-K.: Kil. M.W. Choi, J.-D.: Chang. S.-I. Biodhem. Biophns. Res. Conmmin 1999. 258,797

7. Babczinski. P.: Zelinski. T. Pest. Sci. $1991,31,305$.

8. Choi. J.-D.: Moon. H.: Chang. S.-I.: Chae. J.-K.: Shin. J.-H.: Korean Biochem. J. 1993. 26.471.

9. Schloss. J. V.: Dyk. K. E. V: Vasta. J. F.: Kutny. B. M. Biochentistry 1985. 24. 4952 .

10. Eovang. L : Silverman. P. M. Method Enzmot. 1998. 166.435.

11. Barak Z.; Chipman. D. M. Gollop. N. J. Bacteriol 1989. I69. 3750 .

12. Hill. C. M.: Duggleby. R. G. Biochem. J. 1998. 335.653.

13. Mazur. B. J.: Chui. C.-F.: Smith. J. K. Plant Phnsiol. 1987. 75. 1110 .

14. Hattori. J.: Rutledge, R. G.; Miki. B. L.: Baum, B. R. Can. J. Bot. $1992,70,1957$
15. Grula. J. W: Hudspeth. R. L.: Hobbs. S. L.: Andersont. D. M. Plant Hol. Biol. 1995. 28. 837.

16. Fang. G. Y: Gross. P. R.: Chen, C.-H.; Lillis. M. Plam Mol Biol 1992. 12,1185.

17. Bernasconi, P.: Woodworth. A. R: Rosen. B. A.: Subramanian, M. V: Siehl. D. L. J. Biol. Chem. 1995. 270. 17381.

18. Ott. K.-H.: Kwagh. J.-G.: Stochton. G. W.: Sidrow. V: Kelefuva. G. J.1 Hol Biol. 1996. 263. 359 .

19. Chang. S.-I; Kang, M.-K.: Choi. J.-D; Namgoong, S. K. Biochem. Biophins Res Commm. 1997. 234. 549.

20. Chong, C.-K.: Shin. H.-J.: Chang, S.-I; Choi. J.-D. Biochen Biophys. Res. Commm. 1999. 259.136.

21. Shin. H.-T.: Chong. C.-K.: Chang. S.-I.: Choi. T.-D. Biochem Biophys. Res. Commum. 2000. 271.801.

22. Oh. K.-J.: Park. E.-J.: Yoon, M.-Y: Han, J.-R:: Choi, J.-D Biochem. Biophss Res Commum. 2001. 282. 1237.

23. Yoon. J.-Y; Chung. S.-M.: Chang, S.-I.; Yoon, M.-Y. Han, J.-R.: Choi. J.-D. Biochem. Biophys. Res. Commm. 2002. 293. 433.

24. Chong. C.-K.: Choi. T.-D. Biochem. Biophys. Res. Commun. 2000. 277. 462 .

25. Pang. S. S.: Guddat. L. W; Duggleby, R. G. defa Crnt. 2001. D) 57.1321.

26. Choi. J.-D; Kim. B.-H; Yoon, M.-Y. Bull korem Chem. Soc. 2003. 24. 627 .

27. Lee. B.-W.: Choi. T.-D: Yoon. M.-Y. Bull Koman Chem Soc 2002. 23.765

28. Laemmli. U. K.: Nature $1970,227,680$

29. Bradford. M. M. Anal Biochem. 1976. 72. 248.

30. Choi. J.-D; MeLonnick, D. B. Biochenism 1981, 20. 5722.

31. Sarkar. G.: Sommer. S. S. Biotechique 1990. 8. 404.

32. Sambrook. J.: Fritsch. E. F.: Maniatis. T. Holecular Cloning: A Laboratomy Mamal. 2nd ed.: Cold Spring Horbor Laboratory Press: Cold Spring Horbor, New York. 1989.

33. Saiki. R. K.: Gelfand. D. H.: Stofeel. S.: Scharf. S. J.: Higuchi. R; Horn, G. T.; Mullis, K. B.: Erlich. H. A. Science 1988, 239. 487.

34. Sanger. F.: Nickien. S.: Coulsont. A. R. Proc. Natl Acad Sci. LS.t 1977. 74.5463.

35. Westerfeld. W. W. J. Biol. Chem. 1945. 161. 495.

36. Riordan. J. F. Biochemistm 1973. 12, 3915.

37. Foster, M. Harrison, J. H. Biochem. Biophns Res. Conmm $197+.58 .263$

38. Rohrbach. H. D.: Bodley. J. W. Biochemistry 1977. 16. 1360.

39. Takahashi. K. J. Biol. Chem. 1968. 243.6171.

40. Linders. M. D.: Morkunaite-Haimi, S.: Kinnunen. P. K. J.; Eriksson, O.J Biol Chent 2002. 277,937.

41. Borders. C.: Riordan, J. F. Fed. Proc. Fed Ant Soc. Exp. Biol. 1975.34 .647

42. Vensel. L. A.: Kantrowitz. E. R. J. Biol. Chem. 1980. 255. 7306

43. Chan1. Y. Y.: Cronan1. T. E. J. Bacteriol 1988. 170. 3937. 